\title{
The New Historical Novel: Putting Mid-Twentieth- Century Australia into Perspective
}

Nicholas Birns

\section{(2) OpenEdition \\ 1 Journals}

Electronic version

URL: https://journals.openedition.org/ces/380

DOI: $10.4000 /$ ces.380

ISSN: 2534-6695

Publisher

SEPC (Société d'études des pays du Commonwealth)

\section{Printed version}

Date of publication: 30 November 2018

Number of pages: 7-18

ISSN: 2270-0633

\section{Electronic reference}

Nicholas Birns, "The New Historical Novel: Putting Mid-Twentieth-Century Australia into Perspective", Commonwealth Essays and Studies [Online], 41.1 | 2018, Online since 05 November 2019, connection on 23 August 2021. URL: http://journals.openedition.org/ces/380 ; DOI: https://doi.org/10.4000/ces. 380

\section{(c) $(1) \odot$}

Commonwealth Essays and Studies is licensed under a Licence Creative Commons Attribution - Pas d'Utilisation Commerciale - Pas de Modification 4.0 International. 


\section{The New Historical Novel: Putting Mid-Twentieth-Century Australia into Perspective}

This article argues that, since 2004 or so, a new kind of Australian historical novel has emerged among practitioners of literary fiction, one concerned with the mid-twentieth century. This new historical fiction has been characterized by an aesthetic stringency and self-consciousness. Though Steven Carroll and Ashley Hay will be the principal twenty-firstcentury writers examined, reference will also be made to several other writers including Carrie Tiffany, Charlotte Wood, Sofie Laguna, and to the later work of Peter Carey. In all these contemporary books, technology plays a major role in defining the twentieth century as seen historically.

As the mid-twentieth century recedes into the past, twenty-first-century Australian writers are coming to terms with it in ways that in turn affect their own novelistic practice. Steven Carroll's The Gift of Speed (2004) and Ashley Hay's The Railwayman's Wife (2013) are two prominent examples of this phenomenon. The historical novel - by which, in effect, I mean "the historical novel of late eighteenth- and nineteenth-century Australian exploration, colonization, and settlement," has dominated Australian literature for over a generation. Though conventionally associated with international prize winners such as Peter Carey, Kate Grenville, and Thomas Keneally, this sort of historical novel has been practiced by a great range of writers, from Patrick White to Kim Scott. It has played an important role in rebalancing Australian historiography and culture towards a greater awareness of the ravages of settlement and the durability of the anterior and posterior Indigenous presence of the land. More recently, though, a new sort of historical novel has emerged in Australia, exemplified by the fiction of Ashley Hay in The Railwayman's Wife (2013), Carrie Tiffany in Mateship with Birds (2013), Charlotte Wood in The Submerged Cathedral (2004), and, in the most sustained example, Steven Carroll's Glenroy series, a collection of six books. Moreover, writers whose most famous works have been oriented to the more distant past - Richard Flanagan's The Narrow Road to the Deep North (2013) and Peter Carey's A Long Way from Home (2018) - published novels set in the more recent past. In Sofie Laguna's The Choke (2018), the troubles of a young girl growing up along the Murray River in the early 1970s are exacerbated by her callous and irresponsible father, but are salved by her heroic grandfather, even though the latter suffers from trauma relating to his World War II-era service. This wave of novels features stories all set in the mid-twentieth century and as concerned with temporalities of technology, artifice, and perception as with historical events on a grand scale or a categorical sense of the past as is typically seen in the neo-Victorian colonial novel. One of these developments is the inevitable receding of the twentieth century into history, even as twentieth-century history resonates differently because people are living, and therefore remembering, longer. In addition, media and technology have made the soundscapes and sensations of the near past much more accessible.

Carroll's The Gift of Speed (2004) is the second book in the Glenroy series, which in five books so far (as of 2018) has chronicled middle-class suburban life in Victoria from the 1940s to 1977. The Gift of Speed chronicles the historic tour of the West Indian cricket team to Australia in 1960, the famous "calypso summer" memorable in Australian 
cultural annals, not only in sporting terms but because the prominence it afforded black athletes from the Caribbean played a palpable role in fighting racism in Australia. From Hacker Paine, traumatized by his wartime service, to Peter Black, the Jamesian doctor (meaning "reading Henry James") who speaks of his patient Rita's impending death as "the Distinguished Guest," Carroll loads up the novel with period detail. This detail, however, is not just there as window dressing but to frame the gamut of imaginative possibilities available to his characters.

For the senior generation of contemporary writers, such as Carroll, born in 1949, there is the additional challenge represented by the fact that writing about the past also involves writing about an earlier version of themselves. Michael, who is sixteen in the novel, is five years older than Carroll actually was at the time. He thus cannot be said to be a self-portrait of the author. But Michael is close enough in age to Carroll for Carroll's own memories of the calypso summer to inflect Michael's. The temptation for the writer is to let the power of personal memory, and the vividness and conviction of childhood experience, fuel the engine of imagination. Carroll prudently puts a brake on his own imaginative power by differentiating the point of view of the character by making him five years older. Equally, there might be the temptation to picture the parents, Vic and Rita, and Frank Worrell, the captain - the first black captain - of the West Indian team as quaint period-pieces that serve as background to the emotional growth of the authorial surrogate. This is a temptation that is hard for a coming-of-age novel to resist. Carroll, though, makes Vic, Rita, and Worrell full characters, gets into their heads, makes them three dimensional characters, makes their hopes, fears, and feelings as or even more palpable than those of the young Michael. In other words, he gives as much space and scope to the people about whom he must speculate as to the character he can know at least to some extent by looking into himself. We also have the more peripheral points of view of Vic's dying mother, still struggling with her son's illegitimacy, Black the Jamesian doctor - who would be pleased that his point of view, like all others in the book, is third-person limited - and Webster the factory owner, a neighbor of Vic and Rita, who keeps a secret from his wife that at first seems to be simply a flashy sports car in the garage, but which turns out to be a desire for freedom, even at the cost of life itself. In chapter 33, "The Last Train," all the voices combine in a glorious tone poem.

Most of these characters are invented or fictional. Carroll also gives Worrell, the reallife character, the character on whom documentary research can and in many respects ethically must be done, as much inner life as he does Michael. In fact, when Michael and Worrell fleetingly encounter each other, one feels that the two react with equal interiority, as occurs with Mrs Dalloway's response to Septimus' death, in Virginia Woolf's novel. This is remarkable considering that one of the two characters in Carroll's novel is a famous athlete. Carroll gets into Worrell's head, going into his inner life. Worrell's thoughts range from details of the game to the stress that he, as a man from Barbados, experiences in dealing with players from the other islands. Furthermore, Worrell muses on the Jamesian irony - referring to C.L.R. James in this case - of a formerly white and elite sport to be the medium of this exchange. The American expatriate cricket writer Mike Marqusee saw cricket indeed as a way for the formerly colonized to strike back against the racism and xenophobia of England. Cricket is a game that can be superbly played by professionals, but also enjoyed by amateurs and fans with far less skill but the same interest. Thus, even though Worrell's athletic skill marks him out as excep- 
tional, the ability of others to emulate and follow it renders it something that can also be understood and even empathized with through acts of imaginative participation. Cricket for Michael is both a participant and a spectator sport; and he learns from his cricket fandom to be not just a spectator but also a participant in his society, as it is on the verge of significant change.

The 1960s saw tumultuous change in terms of race relations worldwide, including the independence of most of the African colonies, the civil rights movement in the United States, and the acknowledgment of Indigenous Australians as Australian citizens in 1967. It is very important, with respect to Worrell and the West Indian cricket team, to note that the team was truly transnational - featuring players not just from one country but from the sundry formerly British colonies in the Caribbean, plus islands like Montserrat and Anguilla which remained British possessions. It might be said that the cricket team and the University of the West Indies are the only institutions that the British West Indies - which did not resolve themselves into the formal unity that the various Australian colonies acquired with the 1901 Federation - have in common. But even more crucially, the Calypso Summer took place just before Jamaica, the most populous Anglo-Caribbean nation, became independent. What might have once simply been a reaffirmation of imperial ties became an engagement between separate islands and continents, linked by British influence but no longer needing to directly involve Britain in their lateral interrelationships. We need to be aware of the imperial heritage here, but also to be aware that Australian and West Indian peoples, engaging on separate trajectories and to separate degrees in manifesting de jure autonomy, were also participating, de facto, in a more general modernity. Carroll's novel, while evoking the past in an atmospheric, plangent, and satisfying way, is also about how that past era saw and felt itself to be modern. Pertinent here is how C.L.R. James spoke of the associations and global connections of cricket as "prolegomena" towards an achieved modernity (170). In James's case this is epitomized by the figure of the English cricketer W.G. Grace and, one might surmise, analogously epitomized in the eyes of young Michael by the West Indian cricketer Frank Worrell.

We have been used to thinking about speed and acceleration in modernism in terms derived from Italian futurism or seen in the work of scholars such as Paul Virilio. In this model, speed connotes force, apocalypse, rupture. Carroll's vision of twentiethcentury speed and technology, seen in both this book and in The Art of the Engine Driver, is different: more measured, more gradual, more minute, more integrated in daily life. Speed cannot provide everything; Michael, making a distinction with definite spiritual overtones, differentiates the gift of speed from the gift of grace. As opposed to grace, speed is thus worldly and mutable, and can transpire in different ways in the different athletic skill sets of the West Indian team. It is not a gift involving any inherent morality or immorality. In an extraordinary passage, Michael, on the eve of her farewell to him, finally kisses Kathleen Marsden, the foundling girl from the institution next door and realizes that "there was something out there beyond the sealed, self-enclosed world of speed" (209). Speed is spatial, unbounded, invigorating. But it cannot equal the gift of grace, embodied for Michael by Kathleen's revelation to him of her secret nickname. In cases such as that of Webster, speed can lead to risk and annihilation. But, in suitable hands, it can inspire and even transform. Nor is Michael privileged as a recorder. Indeed, one of the novel's faint comic touches can be seen in the fact that Michael is not 
in attendance or even listening to the radio during many of the key matches, giving his experience of them a sense of futility and peripherality as well as of epiphany. Moreover, it cannot be said that Michael is simply the naïve, young onlooker, and the cricketer Worrell the older, famous hero. Their relationship is too implicit, too evanescent for that. In addition, they are - though hardly like each other - not that different either. The Jamesian doctor spends most of the time dealing with the impeding rencontre of Vic's elderly mother with the Distinguished Guest. But at the end of the novel, the doctor diagnoses problems with Michael's back, finding that playing cricket has given Michael the back of a man decades older, and that he should stop immediately for any but highly recreational purposes. Similarly, Worrell, even at the moment of his sporting triumph, feels a faint tremor that bodes ill health. This foreshadows the fact that Worrell will die within a few years, so his achievement as a racial and postcolonial pioneer is darkened by his truncated life.

One of the other aspects of this recent spate of twentieth century-set fiction is that, because the background does not need to be so explicitly paraded in front of the reader and because a period-appropriate voice does not have to be established, the novel is free to be more concise and to have more moments of implication, such as in the Proustian episodes in legendary cricketer Lindsay Hassett's Sports Store. Yet, if one of the dangers of writing historical fiction about a time not in living memory is that of being archaic, one of the dangers of writing a kind of living-memory historical fiction is that one is always risking uncertainty. By this I mean uncertainty about whether the way people communicated, spoke colloquially or felt during those times is still comprehensible today. It is easier to hypothesize about these small social matters with regard to the longer-term past, where the author knows with more certainty these things were fundamentally different from now, than with respect to the near-term past, where the author may be uncertain and have to think about what practices or technologies were or were not present. An example can be seen in the incident where Mr. Webster, in order to secure Michael's silence about the sports car, gives the boy a ten-pound note; here, the author has to remember what the Australian currency was in 1960, that it was pounds not dollars. This is an example of the kind of detail that comes up in the near past, where the author may be uncertain about just what reference-points of our own reality existed in the fictional world they are creating, and what did not, a question that is raised by any fictional work, but that has to be answered with particular discernment in fiction concerning the near past. Carroll, for instance, presumably is still a cricket fan and follows cricket now, so it must have been hard for him to separate the specific practice of this sort of talk in 1960-61 with what he has picked up in the intervening years.

Carroll is both periodising modernity as he does in his later novels (that fictionalize and place in perspective the personal lives of such literary figures as T.S. Eliot and Iris Murdoch) and suggesting that modernity can be potentially present in any ordinary circumstance. It may well be that contemporary Australian fiction is growing more towards the récit - the short, apparently transparent, but on second examination deeply complicated novel that asks the reader to do a lot of work, as a detective story does. Carroll's style - poetic, yet also spare and austere - fits into this genre, even as the book undertakes an enormous amount of exposition. Some parts of the world have come to expect big, overtly ambitious books from Australian writers, but Carroll's more self-contained practice - or his willingness to stretch his settings and characters into a 
multi-book series, not cram it all into one big book - has gained him acclaim in Europe, most prominently through his shortlisting for the Prix Femina Étranger. Carroll's work is not a cautious, prudent retrenchment to a kind of middle-modernism. His work is far more than that, takes greater risks and asks us to make profound connections between seemingly disparate worlds. Its lack of self-trumpeting does not mean that it does not possess great depth and power.

Michael McGirr's 2004 review of The Gift of Speed in The Age explained that, though sport plays a significant role in Australian culture, it has seldom been the subject of major Australian fiction. This can be partially explained by the fact that despite the global nature of cricket exemplified by the very idea of the West Indian tour, much of the world does not play this particular sport. This renders the novel involuntarily parochial - the same might be argued with regard to the New Zealander Lloyd Jones's Book of Fame, a great rugby novel, or the cricket-inflected poetry of Alan Wearne, Mark Pirie, and Nick Whittock. Yet Carroll's fiction was shortlisted for a major prize in France, hardly known as a heartland of cricket, and Joseph O'Neill's Netherland, a cricket-centered novel, won huge success in the US in 2009. Another point that can be made is that the book is very masculine, dominated by cricket, golf, sports cars - and yet the Jamesian emphasis on the intensities of feeling, combined with the strong characterization of Vic's mother, Rita, and Michael's fleeting love interest Kathleen Marsden, does not make its affect stereotypically masculine, even though the material is. Carroll is writing neither a literary prettying-up of a sporting novel nor a sporting novel with literary aspirations. He is seeing sport as an aspect of human experience, as both a microcosm of life and a rehearsal for our experience of existential limits and mortality. Carroll represents sport as part of ordinary life, sharing its aspirations and silences. Sport is a cultural form with the capacity to embody social change and transformation, the hope that "we all might be just a bit better than we thought we were" (348), but not to cure or to account for personal pain and for the vulnerability of individual experience:

The gift of speed comes in different ways. Michael cannot imagine music in the great Lindwall's ears as he swoops down upon the bowling crease. But he can in the great Worrell's. And when he reaches his delivery stride does the batsman at the other end hear the sound of metal drums and island voices? (20)

Through watching Worrell play cricket, Michael inwardly hears the music of Worrell's Caribbean cultural background. Sport is necessarily external, but The Gift of Speed is a deeply interior book, one which understands that external actions and inner feelings are distinct but can be aligned.

Carroll's fiction has been analyzed, by Nathanael O'Reilly and Brigid Rooney, as exemplary of the novel of suburbia, and by Robert Dixon as an example of scalar modulation and transformation. Yet, I would like to suggest that it plays a more determinative role in contemporary Australian fiction in connecting realism and experimentation, the referential and the aesthetic. The work of Gerald Murnane, in its suburban Melbourne settings, its investment in horse racing, and its sense of the wonder and fragility of love, could be said to echo Carroll's themes, albeit on a much more abstract plane; or one could say Carroll embodies some of Murnane's dreamy impulses in a solider near-past. There is even a resemblance between "reward for effort," the name of the horse in Murnane's racing memoir Something for the Pain that momentarily redeems loss and sorrow, and the sense at the end of Carroll's novel that we might be a bit better 
than we thought we were. This is important because all too often Murnane, a highly self-reflexive and difficult writer, has been walled off from the rest of the Australian literary project. Carroll's work suggests there may instead be connecting commonalities.

Carroll's novel is also concerned with the idea of being a bit better than we were, both artistically or in terms of skill, and socially or in terms of progress; not radically better, but just a bit better. This sense of gossamer if palpable improvement is reminiscent of the phrase "pointless and elegant" (Winton 25) used in reference to surfing in Tim Winton's Breath. In both Breath and The Gift of Speed, there is an odd combination of the revelatory and the gratuitous; Breath, which is taken up with the risky exhilaration inherent in surfing, is, like The Gift of Speed, concerned with sport. Carroll represents a team sport, a situation where progress has to be coordinated. Carroll presents cricket, in its teamwork, sense of tradition, and transnationalism, as a sport which means something beyond the outcomes and statistics of the matches themselves. C.L.R. James, the Caribbean writer who wrote so superbly on the sport, spoke of the game's "fierce, self-imposed discipline" (26) and "vague ideas of freedom." Historical fiction set in the near past has to be about freedom as well as constraint, adjacency as much as distance. Unlike the historical fiction set in the nineteenth century, which always faces the temptation to pastiche Victorian style because it is so distinctive or risks anachronism by writing in a more contemporary style, writing historical fiction of the nearer past does not demand such a stylistic adaptation, although Carroll chooses to write prose which is visionary in its ambition but modest in its scale, scope, and vocabulary, hinting this might be a sustainable prose model for this sort of fiction:

Vic turns his cheek to the wind then looks down to the road passing by beneath him at the wheels of Rita's bicycle spinning around, as he moves to the Old Wheat Road for the morning shopping. It is a familiar path, past the school, its red-brick classrooms quiet under the peppercorns, past the tennis courts, freshly raked and sprinkled, and up into the Old Wheat Road. It's an easy and pleasant ride - best taken in the mornings, before the sun rakes the suburb - and Rita's bicycle, never used by her, is as good as new and travels smoothly. (150)

The words are ordinary, with little verbal extravagance, but the air they conjure is neither humdrum nor mundane. Indeed, there is something heightened, quickened, in Carroll's prose even when he is limning the absolutely ordinary. Even as he muses upon the routine, there is an intense awareness of the losses that life, especially when it is closely examined and meditated upon, has in store for us. Even though Carroll knows his literature, and the Henry James reference is important to this book, Carroll's literariness is less a preoccupation with tradition than a way of representing loss. When Carroll references literature, he is mapping the states of loss his characters feel. This liberates his fiction from the burden of explicit literariness and allows the beauty of Frank Worrell's speed to be its own distinct kind of beauty, not a stand-in for a flamboyantly artistic beauty, without any "attempt to recover the moment of inspiration in which everything that is to be written arrived" (131). The growth of Michael during that calypso summer shows that coordinated progress is able to accommodate both the sheer excellence of grace and a growth into anti-racism that carries undertones of the same grace.

Unlike Carroll, Ashley Hay, born in the 1970s, does not have even vestigial personal memories of the era she writes about in The Railwayman's Wife. But, as in Carroll's novel, Hay deals with the midcentury period in ways both mundane and literary. The 
novel tells the story of everyday Australian destinies that attain a tragic and plangent resonance. Mac Lachlan, a Scottish-born railwayman, meets Anikka Kalm - a surname surely symbolic, as Anikka needs a lot of calm to get through the emotional travails she will endure - in the Riverina of New South Wales; they then go to live in the coastal town of Thirroul, where Mac works on the railway. Although Mac survives World War II, a railway accident in 1948 kills him just before the tenth birthday of his and Anikka's daughter, Isabel. The railway line, as a kind of widow's pension, gives Anikka a job at the railway's library. This job intensifies her acquaintanceship with Roy McKinnon, a friend of Mac's who, however, was a very different sort of person. Roy was an acclaimed poet before the trauma of war silenced him and gave him writer's block. Roy gives the novel a literary aspect as he is visiting his sister, Iris, and her beau, Dr. Frank Draper, to try to inspire his dormant poetry by writing near the sands and waves of Thirroul and Austinmer that inspired D.H. Lawrence's novel Kangaroo, written during a very brief sojourn in Australia.

Through Roy's poetry and Anikka's librarianship, a literary aspect is introduced into a tale of love and mourning that, emotionally, could thrive without the literary. Eleanor Dark's The Timeless Land is mentioned in Hay's novel as a contemporary bestseller. Dark's theme of first contact with the Indigenous people makes it possible for Hay's novel to include an awareness of race and Indigeneity in its purview. As with Carroll having to remember what the Australian currency would have been in 1960, Hay had to think about what a general Australian reader of the late 1940s would be aware of, and what would not be included in his or her readerly horizon. That there are references to Australian as well as world literature in Hay's book is very important as it gives the book an internal literary pedigree and allows for in-references that only the clued-in reader aware of the minute details of Australian literary history can appreciate. It might be that Anikka's sojourn in the Riverina is meant to allude to Joseph Furphy. When Roy's initial efforts at postwar poetry are rejected by his editor, the editor raises instead "another returned poet" (206) who "had spilled the hard, parched landscape of some remote place across his desk that very morning" (206-7); we may be meant to think of the Australian poet David Campbell and the region associated with him, the Monaro, and to juxtapose that hard, flat landscape with the very different coastal emptiness of Thirroul. Most saliently, McKinnon's writer's block recalls a similar issue in the life and work of Kenneth Slessor, the great Australian poet who never wrote a line of poetry after World War II. Hay's novel thus joins Gail Jones's Five Bells (2011) in alluding to Slessor at its edges, and Brian Castro's Street to Street (2013), concerning the earlier poet Christopher Brennan, as contemporary novels that are presenting major Australian poets to the contemporary global reader, who likely has not heard of them, and the contemporary Australian reader who may know the name but little more. Indeed, if the historical fiction of the 1980 s and 1990s, largely set in the settler or colonial era, tended, intentionally or not, to replace the earlier Australian literature the world reader had not read, these newer books are inclined to solicit these earlier poets precisely for the benefit of the world reader and for the Australian reader who should know them better than he or she probably does.

Indeed, the reader of The Railwayman's Wife may well think that literariness is the solution to Annika's loneliness, and love the answer to Roy's creative dejection. Roy, inspired by Anikka, writes a brilliant poem which he sneaks into her house. She reads it, taking in its cadences of lambent lamentation: 
Another sense. In the lost world whose color

And form flared round her, even more intense

And as she passed grew duller. (184)

But Anikka assumes it must be by Mac, that he had written it for her but had not shown it before his untimely death (or perhaps even that it was written by his ghost). We might expect the plot, in a Cyrano-de-Bergerac way, to have Anikka discover that it was really Roy who had written the poem (which Roy reveals through mailing the published version to Anikka), and for her to conclude her period of mourning, and to serve as Roy's enabling muse. But, in a plot twist that likely disappoints even the most rigorous and jaded of literary readers, Roy drowns himself after realizing that "you don't dream of taking a muse by the hand" (248), that his love for Ani is doomed to be literary, not real. Yet there is enough ambiguity in Roy's death - he leaps, perhaps hoping to attain an ultimate, reinvigorating exuberance, not just to die - to make us feel that he has found some redemption. In the wake of this, the reader realizes that his or her initial desire to see Roy and Ani happy together and, even more, to see literariness as a healing agent of love, is contrary to the emotional realities of the novel. Roy feels himself superfluous, not only to Ani, but to his sister Iris and her beau, and, eventually, fiancé, Frank. In a revealing incident, when a bicyclist is killed in Sydney - just after Roy's editor has refused his poetry written before the Anikka poem - Roy gives his name to the police as Dr. Frank Draper, indicating a willingness to have his identity fade into his brotherin-law's, a man who is able to heal his own wartime trauma - he had been a witness to the death camps in Europe - by marrying Iris. He also has a long and instructive talk with Isabel before his drowning. Ani's and Mac's daughter, a precocious child who is carefully made young enough that she could still be alive, if elderly, at the time of the novel's actual publication, 2014, becomes a time-spanning figure like Jocelyn in Wood's Submerged Cathedral or Essie Gormley in Hay's own A Hundred Small Lessons (2017): the reference to Isabel counting "two thousand and fourteen" (48) stars in the sky may have just this application. There is an implied sense, in narratological terms, in which it could be Isabel in effect remembering this story, even though, unlike Carroll's Michael, there is here no possible identity with the author. But although Roy leaves a lasting poetic legacy, his poetry cannot be part of the solution to the character's trauma; he can offer some healing to others, but none to himself. The literary is not salvific. For all the finely wrought, literary cadence of Hay's style, the novel affirms the extraliterary or nonliterary as a category, much as do Carroll's meditations on the beauty of speed. As in Carroll's novel, where sport stands as a register of beauty and form that is aesthetic, but not literary, the beach, the sands, and the railway itself are shown to be tokens of beauty that are illuminated by the literary but not redeemed by it.

The new historical novel of the mid-twentieth century chronicles time that, although slipping into the past, retains a proximity. The first chapter of The Railwayman's Wife has Anikka reflect that "It could be any day, any year, call it 1935, 1938, 1945" (1). It is Anikka's reading that gives her this sense of simultaneity, and it is a kind of layered simultaneity, not a cathartic alterity of having-been, that these novels augur. In Carrie Tiffany's Mateship with Birds (2012), the action is set both remotely - in rural Victoria - and back in time - in the 1950s. Yet this setting is not pastoral, nor does it attempt to absorb the action, to trope on Eleanor Dark's title, into a timeless landscape. The improvised and secondary nature of Henry's relationship with Betty, the way they meet and marry late 
in life, represents adjustment and adaptation, change that in a way is more meaningful because it does not trumpet itself as change. And, much like Tiffany's earlier Everyman's Rules for Scientific Living (2008), which emphasizes the changes wrought on the land by modern farming techniques, Mateship with Birds examines the characters' ever-deepening coexistence with the kookaburras that live on their land with an awareness of how the Anthropocene, and human interference in nature, has changed our idea of the apposition between the human and nonhuman.

If the way Henry instructs Betty's son, Michael, in the mysteries of sex is at times comic and awkward, it also intimates that even "the facts of life" have to be altered and changed in a modernity that being in rural Australia in no way evades. The book manifests an all-pervasive sense of kinship with nature, yet nowhere presumes the organic; Henry and Betty's relationship is constrictive and reparative, but hardly ordinary or foundational. Everyman's Rules contains many pages of agricultural manuals which are not meant as pastiche or to be satirized but scrutinized seriously for their reflection of the states of minds of the characters. This is a corollary of the novel not portraying yesterday, but an earlier form of today. Similarly, in Mateship with Birds, Tiffany describes Hazel, Betty's daughter, borrowing a book from the school library with "pictures of modern cars and trains and aeroplanes" (105). These forms of transportation are forms we still use, albeit in transformed shapes. This kinship to our own practices and technologies enables a respectful conjuring of imagined characters within a real past close enough to our present for us to judge them as we might ourselves. Similarly, in Everyman's Rules for Scientific Living, Tiffany shows how modern technology can quickly become assimilated into the daily. Jean Finnegan, the novel's narrator, sees her "dressmaking mannequins" in the same kitchen as "an electric tea kettle" (193). Tiffany's delineation of everyday technology is neither quaint nor anachronistic. It constructs a past distant from and accessible to us in nearly equal cognitive measures.

Whereas a twenty-first-century novel set in the twenty-first century is going to be global in terms of having to address instantaneous communication and the daily realities of cultural heterogeneity, and a twenty-first-century novel set in the late eighteenth or nineteenth century is going to be global in the sense of colonialism being global, a twenty-first-century novel about the mid-twentieth-century would seem to present Australia as a nation-state reading, albeit in a marginal way, in a world of nation-states. Moreover, the Indigenous issue also is affected by a shift in historical focus to the midtwentieth-century. The issue of Indigenous Australians is bound to be there in colonialera fiction, which must confront their displacement and the usurpation of their land, or in twenty-first-century-set fiction, occurring in the charged atmosphere after the Mabo decision of 1992, the Northern Territory Intervention of 2007, and a far increased awareness of Indigenous issues. Yet the fiction set in the mid-twentieth-century transpires when the Stolen Generation is in the act of being stolen, when Indigenous Australians are not yet citizens, and when a majority of white Australians thought the Indigenous issue belonged either to the past or to eccentrics such as the white Jindyworobak poets who tried to embrace a sort of Indigenous aesthetic. The mid-twentieth-century was not an era when Indigenous Australia was listened to by a majority of the white settler population. Twenty-first-century novelists treating the period have to at once acknowledge this absence and tacitly fill it in with their own implied awareness. 
Peter Carey's A Long Way from Home (2017), a book centered on the Redex Trial, a motor rally that involved cars driving around Australia, is a case in point. Like Carroll in The Gift of Speed, Carey, whose family ran an auto dealership in Bacchus Marsh, Victoria, takes the car as an emblematic instance of mid-twentieth-century technology, as a totem of a particular kind of interaction with the world. Unlike Carroll though, whose fiction is deliberately provincialized and ensconced in suburbia, Carey's chronicling of the Redex Trial, necessarily, takes in the whole of Australia. The novel argues that any attempt to grasp Australia will have to confront the violence and injustice physically and viscerally suffered by the Indigenous people. Through the story of Willie Bachhuber, the navigator in the auto rally who finds he has an Indigenous identity and family of which he was unaware, Carey portrays a modernity coming to terms with a colonialism it thought it had surpassed. Towards the end of the novel, Bachhuber's son says that "my so-called German father had given me the genes that made me Aboriginal" (309), presenting not just a genealogical revelation but an upending of assumptions of racial hierarchies entwined deeply in both Australian identity and modernity itself. The national self-confidence of mid-twentieth-century Australia led to a misplaced conclusion that it had dealt with the Indigenous issue through forced assimilation. This created a false sense of confidence, a feeling that Australian nationhood had been achieved without genocide or interference. By talking about the Indigenous issue in the context of the modern Australian state rather than British colonial structures, Carey's novel shifts the guilt of racism and oppression away from colonial associations. Colonialism can thus be seen by modern white Australians as safely in the past and extrinsic to an emergent Australian identity, which is itself bent towards a modern polity that is hypocritical if it does not admit the continuing dispossession of Australia's first inhabitants. A common theme in these books is the co-presence of science and technology - the railway, the engine, the motor-car, clinical medicine - with historical change, as if science was at once external to this change and in another way part of it or inflecting it.

The twenty-first-century historical novel of the mid-twentieth century must come to terms with technology. In Hay's novel, part of Anikka's mourning process involves understanding that it was Roy, not Mac, who wrote the beautiful poem she finds and shows to her daughter Isabel. When Dr. Frank Draper tells Anikka "Your husband wasn't a poet; he was a railwayman" (262), he is allowing her to continue the mourning process by separating out spheres of imagination and machinery, insisting each has its own validity. That Mac Lachlan was not capable of writing Roy's poem does not make his love for his wife any less radiant. Machinery is put on nearly the same level as art. This is evident in Carey's A Long Way from Home as well, as Titch Bobs's "genius" (5) resides in being a car salesman. Willie Bachhuber's son, in trying to come to grips with the continuing legacy of racism that his father's traumatic midlife realization of his own ancestry had tapped, speaks of analogies to the "encryption" (313) of "alchemical literature." This is an acknowledgment that the historical novel of the mid-twentiethcentury makes a world in which history cannot function alone; that it needs the aid of science, technology, machinery. That Carey, who more than any other novelist is associated with the historical novel of the colonial era, in this late masterpiece turned his attention not just to the mid-twentieth-century but to the particular way the Indigenous issue was embodied there - in suspended half-acknowledgment - shows how what Sue Ryan-Fazilleau termed Carey's postcolonial quest for Australian identity cannot just be 
confined to the nineteenth century, but calls for us to understand the more recent past with just as much scrupulousness and scrutiny.

The world that Peter Carey and Steven Carroll were born in during the 1940s, and that Richard Flanagan, Ashley Hay, Carrie Tiffany, Sofie Laguna, and Charlotte Wood came into in later decades, saw Australia as provincial, as behind the times. A.A. Phillips, in the 1950s, spoke famously of "the cultural cringe," and Geoffrey Blainey of "the tyranny of distance." Australia often blamed itself not just for its own provincialism but, in Phillips's model, for its own self-underestimation in light of that provincialism. But it could be that global modernity, in provincializing Australia, was seeking to divest itself of the association with colonialism and white supremacism that Australian history inevitably proclaimed. This is especially true of avant-garde and left-wing literary movements, who wanted to chart a Euro-American subversion free from EuroAmerican prejudices and imperialisms - to not be equipped with them, but also to not acknowledge them. If one of the motives behind Carey's nineteenth-century-set Australian historical fiction was, as Sue Ryan-Fazilleau put it, to take apart "myths put forward by official Australian history" (11), to write of the mid-twentieth century is to take apart myths fostered by global modernity: that the twentieth century had achieved racial, social, and gender justice when in fact it had not, and that Australia was an uneasy reminder of this lack. That the world now, intermittently, permits Australia to resonate more than it did in midcentury is an index of how the world, intermittently, is coming to terms more with issues of race, empire, and colonialism. What Carroll, Hay, Carey, and Tiffany tell us is how technology and mechanization, and their corollaries in aesthetic form, help bring this story closer to our time. The new Australian novel of mid-twentieth-century history, in juxtaposing different registers of speed - in Carroll's novel, sport, the literariness of loss, and decolonization; in Hay's the war, the surf, the railroad, and the literariness of loss - demonstrates how, as the railwaymen tell Ani Lachlan when informing her of her husband's death, that "an engine, coupled with anything $[\ldots$,$] exerts a powerful lot of force" (27). By placing fictional narratives in a time when$ Australia was no longer a colony, but was still struggling with issues of identity, legitimacy, and its place in global temporality, these novels make a significant contribution to the ongoing Australian literary project. By insisting that Australia, and its legacy of Indigenous dispossession, is part of global modernity, they importantly question that modernity's potential complacency.

Nicholas BIRns

New York University

\section{Works Cited}

Carey, Peter. A Long Way from Home. New York: Knopf, 2018.

Carroll, Steven. The Gift of Speed. Melbourne: Penguin, 2014.

Dixon, Robert. "'Communications from Below': Scalar Transformations in Richard Flanagan's The Narrow Road to the Deep North (2013) and Steven Carroll's A World of Other People (2013)." Antipodes 31.1 (June 2017): article 11. <https://digitalcommons.wayne.edu/antipodes/vol31/iss1/11/>. Flanagan, Richard. The Narrow Road to the Deep North. New York: Vintage, 2014. Hay, Ashley. The Railwayman's Wife. New York: Atria: 2016. James, C.L.R. Beyond a Boundary. Durham: Duke UP, 1993. Jones, Gail. Five Bells, London: Harvill Secker, 2011. 
Marqusee, Mike. Anyone but England: An Outsider Looks at English Cricket. London: Aurum P, 2005.

Murnane, Gerald. Something for the Pain. Melbourne: Text, 2016.

O'Reilly, Nathanael. Exploring Suburbia: The Suburbs in the Contemporary Australian Novel. Amherst, NY: Teneo, 2012.

Rooney, Brigid. "Colonizing Time, Recollecting Place: Steven Carroll's Reinvention of Suburbia."

JASAL 13.2 (Spring 2015): 1-16. <https://openjournals.library.sydney.edu.au/index.php/ JASAL/article/viewFile/9873/9762>.

Ryan-Fazilleau, Sue. "Bob’s Dreaming: Playing with Reader Expectations in Peter Carey's Oscar and Lucinda." Rocky Mountain Review of Language and Literature 59.1 (2005): 11-30.

Tiffany, Carrie. Everyman's Guide to Scientific Living. New York: Scribner: 2006.

—. Mateship with Birds. Sydney: Pan Macmillan, 2012.

Virilio, Paul. Speed and Politics. Trans. Mark Polizzoti. New York: Semiotexte, 2006.

Winton, Tim. Breath. New York: Farrar, Straus, and Giroux, 2008.

WooD, Charlotte. The Submerged Cathedral. Sydney: Vintage, 2014. 